DOI https://doi.org/10.30525/978-9934-26-073-5-1-59

\title{
SPEECH PERSONALITY IN PSYCHOLINGUISTICS (ON THE MATERIAL OF SHERLOCK HOLMES' SPEECH)
}

\author{
Kulish A. R. \\ PhD Student \\ Borys Grinchenko Kyiv University \\ Kyiv, Ukraine; \\ Senior Lecturer at the Department of Philology, \\ Translation and Strategic Communication \\ National Academy of the National Guard of Ukraine \\ Kharkiv, Ukraine
}

Investigations of the peculiarities of the communicative behaviour of the speech personality is a new direction in psycholinguistics. In the field of psycholinguistics, it is distinguished four main areas related to the study of personality: 1) age psycholinguistics; 2) research of norm and pathology in speech; 3) typology of linguistic communities and personalities; 4) characteristics of communicative behaviour of the linguistic personality. Within such researches, different psychological types of a speech personality are defined by separate language features (speech markers) [1].

The aim of the thesis is defined by the identification of the main linguistic features of Sherlock Holmes through the analysis of his speech behaviour taking into account the psychological factor in communication. Despite the interest of scientists in speech personality, there is a noticeable lag in the creation of speech portraits of TV characters in the aspect of psycholinguistics, thereby the relevance of this thesis is marked.

Generally, the study of a speech portrait of a personality in the aspect of linguo personology is carried out by studying the psychological attitudes and level of communicative competence of real representatives of a particular nation with the whole spectrum of speech manifestation. On the contrary, when it comes to a TV character or a protagonist of some work of art, the spectrum of speech manifestation is narrowed and restricted to a certain communicative situation (discourse) [8]. This explains the problematic of the thesis because the material of our research is the British TV series "Sherlock".

Researches on the typology of speech personality depending on the characteristics of discursive behaviour (communicative strategies, communicative competence, speech culture) of the individual are laid in the works of O. Pushkin, O. Syrotynina, V. Holdin, I. Susov, S. Sukhykh, etc. I. Susov [5] recognizes the construction of a typology of speech personalities, based on 222 
speech acts, techniques, tactics and strategies of the individual in the process of communication. O. Pushkin [4] concludes that the type of personality depends on the structure of its discourse. S. Sukhykh [6] turns to the study of the pragmatic level of speech personality and, depending on the attitude of the communicant and hislher personality traits, identifies a harmonious, conflict and impulsive psychotypes of speech personality.

The subject of this thesis is the linguistic characteristics of Sherlock Holmes' speech behaviour. Respectively, the object of the thesis is the speech personality of Sherlock Holmes. The material of the research is audio and video recordings and scripts of the TV series "Sherlock" [9; 10]. The series have 4 seasons, each of which includes 3 episodes, i.e. a total of 12 episodes. In each episode there is a certain set of lexical and grammatical characteristics that describe Sherlock Holmes as a speech personality with a certain psychotype.

Before analyzing the speech personality of Sherlock Holmes, we need to reveal the meaning of each of the psychotypes. The harmonious psychotype is characterized by the flexible and dynamic attitudes to the general theme of communication, coherence of the developing topic; the dominance of markers of confidence, compliance with social norms during the conversation, the absence of struggle for the role of communicative leader, the ability to change attitudes under the influence of argumentation, maintaining the principles of communicative cooperation. Conflict psychotype is characterized by the rough and static attitudes, impulsiveness, leadership in communication, self-centered speech, violation of the coherence of the conversation topic, rejection of social norms during the conversation, conflict of intentions during a conversation, dominance of linguistic markers with the meaning of uncertainty, the presence of irony and sarcasm in speech. The impulsive psychotype obeys the communication situation. It is characterized by the desire to gain leadership in communication, violation of the coherence of the conversation topic, sharp change of the topic of communication [6].

In order to determine the psychotype of Sherlock Holmes' speech behaviour, we used the following parameters: general attitude of the speech personality to the process of communication, role and status in communication, compliance with social norms during the conversation, coherence of the topic of conversation, intentions of the communicant.

\section{References:}

1. Куранова С. І. Проблеми дослідження мовної особистості у психолінвістиці / С. І. Куранова // Вісник Маріупольського державного університету. Серія: Філологія. 2017. Вип. 16. С. 90-97. 
2. Морякіна I. А. Мовна особистість у художній прозі Дж.Голсуорсі: лінгвокогнітивний та прагматичний аспекти (на матеріалі романів форсайтівського циклу): автореф.дис... канд;філол.наук: 10.02.04 / Ірина Анатоліївна Морякіна. Київ: Б.в., 2005. 20 с.

3. Прохоров Ю. Е. Действительность. Текст. Дискурс. М.: Флинта, 2006. $224 \mathrm{c}$.

4. Пушкин А. А. Способ организации дискурса и типология языковых личностей // Язык, дискурс и личность: Межвузовский сб. научных трудов. Тверь: Изд-во ТГУ, 1990. С. 50-60.

5. Сусов И. П. Лингвистическая прагматика. М.: «Восток-Запад», 2006. $323 \mathrm{c}$.

6. Сухих С. А. Личность в коммуникативном процессе / С. А. Сухих. Краснодар: ЮИМ, 2004. 156 с.

7. Biber, D., Conrad, S., and Reppen, R. (1998). Corpus Linguistics. Cambridge University Press, Cambridge

8. Brown, G. and Yule, G. (1983). Discourse analysis. Cambridge University Press, Cambridge.

9. Sherlock transcripts (1-3 seasons). Forever dreaming. Retrieved from https://transcripts.foreverdreaming.org/viewforum.php? $\mathrm{f}=51$ (access date: 25-30.03.21)

10. Translation in context. Sherlock in the original version with English subtitles. URL: https:// www. opensubtitles. org/en/ ssearch/ sublanguageideng/idmovie-59571(access date: 25-30.03.21)

DOI https://doi.org/10.30525/978-9934-26-073-5-1-60

\title{
РОЛЬ КОНТЕКСТУ В МОВЛЕННСВІЙ РЕАЛІЗАЦІЇ ФРАЗЕОЛОГІЗМІВ
}

\author{
Матвіснків О. С. \\ кандидат філологічних наук, \\ доцент кафедри іноземних мов для гуманітарних факультетів \\ Львівського національного університеут імені Івана Франка \\ м. Львів, Украӥна
}

Фразеологія віднаходить широке застосування у художній літературі. У британських художніх текстах мовлення / дискурс антропоморфів значно відрізняється від наукової і побутової форм, і слугує для створення конкретного естетичного та емоційно-художнього впливу на 224 